\title{
OXIDO-REDUCTIVE BRAIN STATUS AFTER ACUTE ALUMINIUM POISONING - THE ROLE OF FREE RADICALS
}

MILOVANOVIĆ ANĐELA*, MILOVANOVIĆ J*, KONSTATINOVIĆ LJUBICA**, VIĆENTIĆ S***,

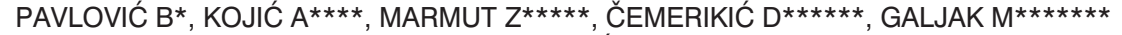
and MILOVANOVIĆ $\mathrm{A}^{\star \star \star \star \star \star \star \star \star \star}$

\footnotetext{
*University of Belgrade, Faculty of Medicine, Clinical Centre of Serbia, Belgrade;

**University of Belgrade, Faculty of Medicine, Institute for Rehabilitation, Belgrade; ***General Hospital "Dr Laza Kostić Lazarević" Šabac; ****Institute of Orthopedic Surgical Diseases "Banjica", Belgrade; $* \star \star \star *$ University of Belgrade, Faculty of Medicine, Institute of Hygiene and Medical Ecology, Belgrade; $* * * * *$ University of Belgrade, Faculty of Medicine, Institute of

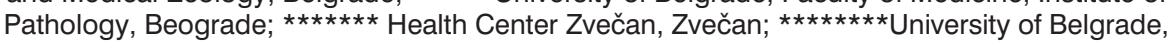
Faculty of Medicine, Serbian Institute of Occupational Health, Belgrade
}

$$
\text { (Received 5 } 5^{\text {th }} \text { October 2012) }
$$

Free radicals induce oxidative processes which damage and inactivate many intracellular components and may cause cell death. This paper presents the results of experiments performed on desert mice (gerbils), adults of both sexes. After acute intraperitoneal administration of aluminium, the oxido-reductive brain state was investigated in the cerebral cortex, hippocampus and nucleus caudatus brain structures. We observed a decrease in defense capacities of the brain - decrease of superoxide dismutase and glutathione reductase activity, with a simultaneous increase in the quantity of malondialdehyde, which indicates that under the influence of aluminium the brain capacity to neutralize superoxide radicals is significantly decreased, and that the consequence is increased generation of free radicals which damage the membrane and results in the formation of malondialdehyde from membrane lipids thus breaking the functional integrity of the cell. Acute $A /^{3+}$ administration caused a dose-dependent increase in the quantity of malondialdehyde in the cerebral cortex and hippocampus, while in the nucleus caudatus this effect was somewhat less pronounced. Mitochondrial superoxide dismutase was more sensitive to the administration of $A /^{3+}$ than tissue superoxide dismutase.

Key words: acute aluminium poisoning, brain, free radicals, oxido-reductive stress

\section{INTRODUCTION}

Molecular oxygen is necessary for the life of aerobic organisms as it is the terminal electron acceptor in oxidative processes which provide the energy 
necessary for cell metabolism. Disturbed oxygen homeostasis can lead to hypoxia or tissue ischemia, thus leading to the production of free radicals in situations when interruption of the electron flow occurs through the respiratory chain. Free radicals induce strong oxidative processes which damage and inactivate many intracellular components which may cause cell death (Mršulja, 1986; Weiss, 1986).

\section{Cell mechanisms of protection from free radicals}

The cell is protected from free radicals in several ways. Primarily, it has enzyme systems which neutralize superoxide anions, hydrogen peroxide and lipid peroxides: superoxide dismutase, catalase and peroxidase. Cell enzymes which enable proper action of antioxidative enzymes are also important: glutathione reductase, glucose-6-phosphate dehydrogenase etc. The cell also has endogenous neutralizers of free radicals: tocopherol, ascorbic acid, peptides with thiol group (Ikeda, 1990; Sies, 1985). The integrity of cell structures which enable separation of the occurring free radicals is also important (Siesjo, 1981).

Superoxide dismutase (SOD) is a metalloenzyme, which in mitochondria occurs in the form of a tetrameric manganese-enzyme complex, and in the cytoplasm as a dimeric copper-zinc-enzyme complex (Sies, 1985). SOD catalyzes dismutation of superoxide anion into hydrogen peroxide and in that way neutralizes the superoxide anion (Weiss, 1986).

Catalase and peroxidase have a significant role in the adjustment of the concentration of hydrogen peroxide in the cell. When hydrogen peroxide is quickly formed, catalase enables the reaction of hydrogen peroxide dismutase.

Glutathione peroxidase catalyzes the reaction of hydrogen peroxide with reduced glutathione (GSH), which produces oxidized disulfide glutathione (GSSG) and water.

Nicotinamide adenine dinucleotide phosphate (NADPH) is regenerated in the hexamonophosphate shunt or in the reaction of isocitrate dehydrogenase (Halliwell and Gutteridge, 1985).

Tocopherol is an endogenous antioxidant, which at high oxygen concentrations breaks the chain of reactions of lipid peroxidation when reacting with lipid radicals, forming a stable vitamin E-radical. Vitamin E-radical can be reduced to vitamin $E$ in the reaction with ascorbic acid (Weiss, 1986).

Beta-carotene as an endogenous antioxidant breaks the chain of reactions of lipid peroxidation when oxygen levels are low. Tocopherol and beta-carotene remove singlet oxygen by transferring the energy from singlet oxygen to the accepting molecule (Sies, 1985; Weiss, 1986).

\section{Absorption}

Aluminium is absorbed into the body mainly by inhalation or ingestion. Percutaneous absorption is insignificant. Most often aluminium vapor and sulphate or silicate aluminium oxide particles are inhaled. Submicron particles are phagocytosed by microphages of lung alveoli and transported into lymph nodes. It has been proven that aluminium from macrophage lysosomes is released and deposited in the body. Daily, $10-100-160 \mathrm{mg}$ of aluminium is ingested by food and 
Acta Veterinaria (Beograd), Vol. 63, No. 2-3, 145-157, 2013.

Milovanović Anđela et al.: Oxido-reductive brain status

after acute aluminium poisoning - the role of free radicals

water, mostly in insoluble form, which is eliminated by feces. The soluble form is absorbed by a mechanism which has not been completely explained. It was found that the parathyroid hormone and citric acid increase intestinal absorption of aluminium.

In the circulation, most of aluminium (60-80\%) is bound to plasma proteins. Most of it is bound to plasma albumins in calcium binding spots. A small quantity is in the colloidal form or bound to high molecular weight proteins (macroglobulins, haptoglobin, IgM, or orosomucoid). The diffusable, ultrafilterable fraction of plasma aluminium bound to proteins of low molecular weight, the identity of which is still not known, is particularly interesting. This fraction constitutes $20-40 \%$ of plasma aluminium; it increases with the increase of total plasma aluminium, and most probably is responsible for the toxic effects. The rest of approximately $30 \%$ of blood aluminium is bound to erythrocytes by a mechanism which has not been explained.

\section{Distribution in the body}

Distribution of aluminium has not been studied enough due to the lack of stable radioactive isotopes. Rats poisoned orally or parenterally accumulate aluminium in the liver, kidneys, adrenal glands, brain, muscles, bones and bone marrow. In humans, the highest concentrations are found in the lungs, they increase with age (unlike in other organs), and probably are deposits of inhaled aluminium particles. Some data indicate that the concentration of aluminium in the brain increases with age. Patients with chronic renal insufficiency accumulate significantly larger quantities of aluminium, which in some organs increase up to 200 times.

\section{Pathogenesis of damage}

Biological effects of aluminium have not been completely elucidated. Some data indicate that the bond of aluminium with enkephalin is most probably responsible for neurotoxic effects of aluminium. It was discovered that aluminium makes an allosteric block in the activation of calmodulin, and by binding it to chromatin causes inhibition of corticosterone binding. It also participates in the fluoride activation of adenylate cyclase. Other biological effects are complement activation, inhibition of thrombocyte aggregation induced by ristocetin, inhibition of cytoplasmic and mitochondrial hexokinase and binding to transferrin. aluminium most probably binds to tryptophan residues in transferrin, while zinc and gallium competitively bind to receptor sites (Mazarguil, 1982; Sternweis, 1982; Siegel, 1983; Sanderson, 1982; Ramanathan, 1979; Baugh, 1975; Womack, 1989; Tomimatsu, 1976).

Intracellularly, aluminium is localized in the lysosomes, most probably in the form of phosphate. Lysosomes contain a large number of enzymes which, apart from other roles of theirs, maintain th metal concentration, such as gallium, indium and aluminium. Aluminium from the extracellular fluid, where small concentrations in the soluble form are found, is most probably actively transported through the lysosomal membrane, and acid phosphatase plays an important role in selective concentrations. Intralysosomal precipitation of 
insoluble aluminium phosphate is a phenomenon of detoxification since it is considered that insoluble aluminium is not toxic. However, long term accumulation of large quantities of aluminium in lysosomes is incompatible with cell life (Bery, 1978; Berry, 1982).

\section{MATERIAL AND METHODS}

The oxido-reductive brain state was investigated in the surface - cortex (Cx), and deep - hippocampus (Hipp) and nucleus caudatus (nCd) brain structures. Parameters for oxido-reductive stress were: activity of superoxide dismutase SOD, both total and mitochondrial, as well as glutathione reductase - GR and malondialdehyde - MDA.

\section{Experimental}

The experiment involved desert mice (Meriones unguiqulatus), adults of both sexes, of approximate body weight of $75 \mathrm{~g}$, raised in standard laboratory conditions, at constant room temperature, with food and water ad libitum.

Aluminium $\left(\mathrm{AlCl}_{3} \times 6 \mathrm{H}_{2} \mathrm{O}\right.$ M.T. 241.45 - Kemika Zagreb) was administered intraperitoneally to non-anesthetized animals. aluminium was administered intraperitoneally at $L D_{50}$ dose of $3.7 \mathrm{~g}$ per kilogram of body weight.

The first group of animals was the control group, and was treated only with saline solution. The animals were sacrificed by decapitation.

Animals were treated with aluminium in acute form as $L_{25}$ and $L D_{50}$. aluminium solution was administered intraperitoneally at a single dose of $0.4 \mathrm{~mL}$ per animal, and they were sacrificed two hours after the administration.

Immediately after decapitation of experimental animals, their heads were frozen in liquid nitrogen and kept at $-20^{\circ} \mathrm{C}$ until time for tissue preparation. Brain structures- cortex (Cx), hippocampus (Hipp) and nucleus caudatus (nCd), were separated on ice $\left(0-4^{\circ} \mathrm{C}\right)$ by a quick procedure and immediately homogenized in a glass homogenizer by Teflon pestle in $1.5 \mathrm{~mL}$ of saccharose medium $(0.25 \mathrm{M} / \mathrm{L}$ saccharose, $10 \mathrm{mmol} / \mathrm{L} \mathrm{K} / \mathrm{Na}$ phosphate buffer, $\mathrm{pH} 7.0$ and $1 \mathrm{mmol} / \mathrm{EDTA}$ ). Immediately after homogenization, samples were centrifuged at $3.000 \mathrm{rpm}$ during 15 minutes (Beckman J-21, rotor J-20). The obtained supernatant was discarded and the sediment was mixed with $1.5 \mathrm{~mL}$ of saccharose medium. After that it was centrifuged again at the same number of revolutions for the same time, in the same centrifuge. The supernatant was added to the previous supernatant and frozen at $-20^{\circ} \mathrm{C}$ until the moment the content and activity of superoxide dismutase (SOD), glutathione reductase (GR) and malondialdehyde (MDA) were determined.

Determination of superoxide dismutase (SOD) activity

The activity of superoxide dismutase (SOD) was measured as the percent of inhibition of epinephrine autoxidation under base conditions by tissue sampling. SOD catalyzes the following reaction:

$$
. \mathrm{O}_{2^{-}}+. \mathrm{O}_{2^{-}}+2 \mathrm{H}^{+} \rightarrow \mathrm{H}_{2} \mathrm{O}_{2}+\mathrm{O}_{2}
$$

thus removing. $\mathrm{O}_{2}$ - and inhibiting spontaneous autoxidation of epinephrine. 
Acta Veterinaria (Beograd), Vol. 63, No. 2-3, 145-157, 2013.

Milovanović Anđela et al.: Oxido-reductive brain status

after acute aluminium poisoning - the role of free radicals

The activity of total SOD was measured kinetically, as the change of extinction in time (10 minutes) at $480 \mathrm{~nm}$ wavelength (Sun, 1978).

The reaction mixture contained $\mathrm{Na}$-bicarbonate buffer $(50 \mathrm{mmol} / \mathrm{l}, \mathrm{pH} 10.2)$ and epinephrine $(0.5 \mathrm{mmol} / \mathrm{L})$ and $0.1 \mathrm{~mL}$ of the sample; the reaction started by adding $0.1 \mathrm{~mL}$ of epinephrine solution $(0.01 \mathrm{M}$ into $0.01 \mathrm{M} \mathrm{HCl})$.

Change of extinction of the same reaction mixture into which $0.1 \mathrm{~mL} 0.01 \mathrm{M}$ $\mathrm{HCl}$ was added was used as a blind trial relative to which the inhibition was calculated.

Activity of SOD was presented as a number of international units (IU)/mg of protein. International unit is defined as the activity of enzyme which causes $50 \%$ inhibition of epinephrine autoxidation.

Glutathione reductase activity: oxidized glutathione oxidoreductase, EC 1.6.4.2; GR

In the presence of $\mathrm{NADPH}$, glutathione reductase reduces oxidized glutathione and $\mathrm{NADP}^{+}$is formed. Fluorescence is developed after adding a strong base, and is measured at $340 \mathrm{~nm}$ wavelength of light at emission of $450 \mathrm{~nm}$.

The reaction mixture contained TRIS-HEPES buffer $(110 \mathrm{mmol} / \mathrm{L}, \mathrm{pH} 7.2)$, Na-ethylenediaminetetraacetate (EDTA) (1 $\mathrm{mmol} / \mathrm{L})$, oxidized glutathione $(10 \mathrm{mmol} / \mathrm{L})$ and $\mathrm{NADPH}(1 \mathrm{mmol} / \mathrm{L})$. The reaction was induced by adding $0.01 \mathrm{~mL}$ of the sample into $0.2 \mathrm{~mL}$ of reaction mixture. After 15 minutes of incubation at $37^{\circ} \mathrm{C}$ the reaction was terminated by $0.1 \mathrm{~mL} \mathrm{HCl}(1 \mathrm{M})$, which destroys $\mathrm{NADPH}$, and $1 \mathrm{~mL} \mathrm{NaOH}(6 \mathrm{M})$ was added to the samples. Fluorescence was measured 30 minutes after incubation at $37^{\circ} \mathrm{C}$ (Lowry, 1974). Identified quantities of $\mathrm{NADPH}^{+}$in the indicator mixture were used as the standard.

\section{Establishing the index of lipid peroxidation}

Thiobarbituric acid (TBA) reacts with free malondialdehyde (MDA) from polyunsaturated fatty acids in the process of peroxidation, creating a pink colored complex. The quantity of the obtained MDA is measured by spectrophotometry and it is an index of lipid peroxidation. The process of peroxidation is initiated by in vitro adding iron ions, copper ion, ascorbic acid, or some other pro-oxidants. Although TBA can also react in an unspecific way with other aldehydes and some sugars, this reaction was widely accepted for measuring the product of lipid peroxidation (Villacara, 1989).

The reaction mixture (TBA) contained trichloroacetic acid (150 g/L), hydrochloric acid $(0.25 \mathrm{M} / \mathrm{L})$ and thiobarbituric acid $(3.75 \mathrm{~g} / \mathrm{L})$. Lipid peroxidation in samples was stimulated by adding $0.025 \mathrm{~mL} \mathrm{FeSO} 4(0.01 \mathrm{mmol} / \mathrm{L})$ and $0.025 \mathrm{~mL}$ of ascorbic acid $(0.5 \mathrm{mmol} / \mathrm{L})$. Protein content in the samples was corrected to $0.2-0.3 \mathrm{mg} / \mathrm{mL}$ by dilution with TRIS-HCl buffer $(50 \mathrm{mmol} / \mathrm{L}, \mathrm{pH} 7.4)$. Peroxidation occurred during one hour incubation at $37^{\circ} \mathrm{C}$, in the atmosphere saturated with water steam. Reaction was interrupted by adding $1 \mathrm{~mL}$ of cold reaction mixture (TBA). The color was developed by heating at $95^{\circ} \mathrm{C}$ during 15 minutes. After that, the samples were centrifuged at $1000 \mathrm{~g}$ (Beckman J-21, rotor 
J-20) during 10 minutes. Supernatant extinction reading was done at $533 \mathrm{~nm}$. A control in which peroxidation was not stimulated was performed for each sample.

From a larger number of series of standard curves in the range from $100 \mathrm{nmol}$ to $100 \mathrm{M}$ (Villacara et al., 1989), extinction molar coefficient for MDA of $1.56 \times 10^{5}$ mols was ascertained. Lipid peroxidation index was expressed as nmol $\mathrm{MDA} / \mathrm{h} / \mathrm{mg}$ of protein.

\section{Statistical analysis of the results}

In each group there were 6-10 animals. All the values are expressed as mean value $(X) \pm$ standard deviation $(S D)$ of the mean value $(X)$. Comparison of the experimental groups was performed by Student's t-Test for Small Independent Samples (variances were homogenous in all the observed groups). As a statistically significant difference, the difference between groups for probability of "zero" hypothesis (there are no differences between the observed parameters) less than 0.05 was accepted. Statistical data analysis was performed by computer program Pharmacologic Calculation System - Version 4.0 for PC.

\section{RESULTS}

Activity of total SOD in the cerebral cortex significantly decreased $(p<0.01)$ in acute aluminium administration of $L_{25}$ dose. Administration of $L D_{50}$ dose resulted in the increase of total SOD activity. Mitochondrial SOD followed these changes.

Table 1. Activity of SOD enzyme in the cerebral cortex after acute administration of aluminium

\begin{tabular}{|c|c|c|}
\hline Group & Total SOD X SD & Mitochondrial SOD X SD \\
\hline \hline Control & $22012 \pm 1521$ & $14578 \pm 1372$ \\
\hline $\mathrm{LD}_{25}$ & $11810 \pm 1578$ & $5932 \pm 1270$ \\
\hline $\mathrm{LD}_{50}$ & $32548 \pm 1329$ & $22053 \pm 4150$ \\
\hline
\end{tabular}

*SOD activity is presented as $\mathrm{mlU} / \mathrm{mg}$ of protein

Activity of total SOD in the hippocampus is significantly decreased $(p<0.01)$ in acute aluminium administration of $\mathrm{LD}_{25}$ and $\mathrm{LD}_{50}$ doses. Mitochondrial SOD shows significant drop of activity $(p<0.01)$ in acute aluminium administration of $\mathrm{LD}_{25}$ dose, while at $\mathrm{LD}_{50}$ dose SOD activity is insignificantly greater (NS).

Activity of enzyme of total SOD in nucleus caudatus is significantly decreased $(p<0.01)$ in acute aluminium administration of $L_{25}$ dose. $L D_{50}$ dose does not show significant change of activity (NS). Mitochondrial SOD also follows the changes, so we observed significant drop of activity for $L_{25}$, approximately three times relative to the control $(p<0.01)$, while for $L_{50}$ there is no significant difference (NS). 
Acta Veterinaria (Beograd), Vol. 63, No. 2-3, 145-157, 2013.

Milovanović Anđela et al.: Oxido-reductive brain status

after acute aluminium poisoning - the role of free radicals

Table 2. Activity of SOD enzyme in hippocampus after acute aluminium administration

\begin{tabular}{|c|c|c|}
\hline Group & Total SOD X SD & Mitochondrial SOD X SD \\
\hline \hline Control & $24500 \pm 1685$ & $17757 \pm 579$ \\
\hline $\mathrm{LD}_{25}$ & $12668 \pm 2037$ & $7037 \pm 1696$ \\
\hline $\mathrm{LD}_{50}$ & $34559 \pm 1494$ & $20912 \pm 2124$ \\
\hline
\end{tabular}

*SOD activity is presented as $\mathrm{mlU} / \mathrm{mg}$ of protein

Table 3. Activity of SOD in the nucleus caudatus after acute aluminium administration

\begin{tabular}{|c|c|c|}
\hline Group & Total SOD X SD & Mitochondrial SOD X SD \\
\hline \hline Control & $23520 \pm 2417$ & $15495 \pm 1137$ \\
\hline $\mathrm{LD}_{25}$ & $10001 \pm 601$ & $5202 \pm 1042$ \\
\hline $\mathrm{LD}_{50}$ & $35810 \pm 6558$ & $23655 \pm 3334$ \\
\hline
\end{tabular}

*SOD activity is presented as $\mathrm{mlU} / \mathrm{mg}$ of protein

In acute aluminium exposure to $\mathrm{LD}_{25}$ and $\mathrm{LD}_{50}$ the activity of glutathione reductase is in some cases several times lower relative to the control group and the difference is significant $(p<0.01)$.

The activity of glutathione reductase enzyme in the hippocampus is significantly decreased in acute treatment, both for $L D_{25}$ and $L D_{50}$. The enzyme activity in some cases is several times decreased $\left(\mathrm{LD}_{50}\right.$ - three to four times decreased activity).

The activity of glutathione reductase in the nucleus caudatus in acute aluminium administration shows several times less activity both for $L D_{25}$ and $L D_{50}$ doses relative to the control group $(p<0.01)$.

Table 4. Activity of GR in the cerebral cortex, hippocampus and nucleus caudatus after acute aluminium administration

\begin{tabular}{|c|c|c|c|}
\hline \multirow{2}{*}{ Group } & \multicolumn{3}{|c|}{ Acute X SD } \\
\cline { 2 - 4 } & Cerebral cortex & Hippocampus & Nucleus caudatus \\
\hline \hline Control & $45.38 \pm 2.30$ & $61.18 \pm 3.74$ & $56.22 \pm 2.89$ \\
\hline $\mathrm{LD}_{25}$ & $9.16 \pm 2.76$ & $41.23 \pm 5.25$ & $15.17 \pm 1.31$ \\
\hline $\mathrm{LD}_{50}$ & $17.75 \pm 3.89$ & $23.00 \pm 3.93$ & $22.00 \pm 5.60$ \\
\hline
\end{tabular}

*Activity of glutathione reductase is presented as $\mathrm{nmol} / \mathrm{mg}$ of protein $/ \mathrm{h}$ 
Quantity of MDA in acute poisoning in different structures of CNS cortex, hippocampus, and nucleus caudatus

Quantity of malondialdehyde in the cerebral cortex is insignificantly increased at $L D_{25}$ by $40 \%$, while at $L_{50}$ this difference is several times larger, and thus significant $(p<0.01)$.

The MDA quantity in the hippocampus is insignificantly larger relative to the control group for $L_{25}$, while for $L D_{50}$ it resulted in multiple increase $(700 \%)$ after acute treatment.

The MDA quantity in the nucleus caudatus does not show significant increase in acute treatment at $\mathrm{LD}_{25}$ and $\mathrm{LD}_{50}$.

Table 5. Quantity of MDA in the cerebral cortex, hippocampus and nucleus caudatus after acute aluminium administration

\begin{tabular}{|c|c|c|c|}
\hline \multirow{2}{*}{ Group } & \multicolumn{3}{|c|}{ Acute X SD } \\
\cline { 2 - 4 } & Cerebral cortex & Hippocampus & Nucleus caudatus \\
\hline \hline Control & $0.167 \pm 0.026$ & $0.155 \pm 0.008$ & $0.182 \pm 0.003$ \\
\hline $\mathrm{LD}_{25}$ & $0.233 \pm 0.03$ & $0.187 \pm 0.05$ & $0.33 \pm 0.156$ \\
\hline $\mathrm{LD}_{50}$ & $1.17 \pm 0.007$ & $1.24 \pm 0.06$ & $0.39 \pm 0.06$ \\
\hline
\end{tabular}

*MDA quantity is presented as $\mathrm{mmol} \mathrm{MDA} / \mathrm{mg}$ of protein

\section{DISCUSSION}

The key aluminium effect on oxidative brain state is the decrease in defense capacities - decrease of enzyme activities, superoxide dismutase (SOD) and glutathione reductase (GR), with a simultaneous increase in the quantity of malondialdehyde (MDA) (Tables 1-4). This indicates that under the influence of aluminium the brain capacity to neutralize superoxide radicals is significantly decreased, and that the consequence of that is increased generation of free radicals which damages the membranes and results in the formation of malondialdehyde from membrane lipids, which most definitely results in the loss of functional integrity of the cell.

Altered enzyme activity is considered to be one of the pathogenic effects through which aluminium causes brain damage. After exposition to heavy metals, this altered enzyme activity may to some extent be explained by the affinity for sulfhydryl groups of enzymes, but in exposition to aluminium, as well as other trivalent cations, this mechanism cannot be applied since it was experimentally proven that this group of cations does not show an affinity to bind to sulfhydryle groups (De Vernjoul, 1983). However, some researches show that free radicals demonstrate toxic effects of aluminium (Mitrović, 1987). By interfering with iron metabolism (ferrous ion as trivalent cation is included in a large number of oxidoreductive cell processes), aluminium causes the occurrence of large quantities of free radicals (Joshi, 1990, 1991). Aluminium, $\mathrm{Al}^{3+}$ builds up a complex with $\mathrm{O}^{2-}$, which shows more aggressive properties than $\mathrm{O}^{2-}$ (Kong, 1992). This was 
confirmed by data proving that in aluminium exposition there is increased peroxidation of lipids (Lal, 1993; Bulat, 1995). Our results (Table 5) are in accordance with the findings that the content of MDA, is significantly increased in the experimental groups.

In acute aluminium administration there was a significant inhibition of total, as well as mitochondrial SOD at $\mathrm{LD}_{25}$ in all observed structures. The activity of total SOD in the cerebral cortex decreased by $50 \%$ relative to the control, in the hippocampus by $48 \%$ of the control value, and in the nucleus caudatus by $57 \%$ of the control value (Tables 1,2,3). A similar trend appeared in the activity of mitochondrial SOD. SOD activity in the cerebral cortex decreased by $60 \%$ of the control value, in the hippocampus by $60 \%$ of the control value, and in the nucleus caudatus by $66 \%$ of the control value (Tables $1,2,3$ ). This indicates that sensitivity of mitochondrial SOD to acute $\mathrm{Al}^{3+}$ poisoning is higher. This is of relevance considering the fact that mitochondria are the principal site of generation of free radicals in normal circumstances. This finding indicates that mitochondria are the most sensitive spot. This also indicates the possibility of energy metabolism disorders as the secondary effect of $\mathrm{Al}^{3+}$ is on the mitochondria, which additionally increases primary oxidative damage. Somewhat a paradox, larger doses of aluminium $\left(\mathrm{LD}_{50}\right)$ resulted in increased or unchanged SOD activity (Tables 1, 2, 3). We have observed an increase in total SOD (at $L_{50}$ ) in the cerebral cortex by $47 \%$ relative to the control, in the hippocampus an increase of $40 \%$ relative to the control, and in the nucleus caudatus SOD activity was increased by $52 \%$. It was similar with mitochondrial SOD (Tables 1, 2, 3), where we had the increase in mitochondrial SOD in the cerebral cortex by $51 \%$ relative to the control value, in the hippocampus the increase was $18 \%$ relative to the control, and in the nucleus caudatus the increase was $53 \%$ relative to the control value. This might reflect individual resistance of animals undergoing $L D_{50}$, i.e. that only animals with high SOD activity and/or animals with easily inducible SOD can survive high doses of aluminium. However, this effect is transient since in chronic experiments there is no difference in $\mathrm{Al}^{3+}$ action at different doses. This probably indicates the transient nature of SOD induction at high doses of $\mathrm{Al}^{3+}$ and opens up an interesting question whether there is a protective effect of $\mathrm{Al}^{3+}$ in biological systems.

Glutathione reductase activity in acute aluminium administration is decreased at $L D_{25}$ and $L D_{50}$, i.e. no differences were observed in the SOD reaction to aluminium (Table 4). However, in the cerebral cortex and in the nucleus caudatus both doses caused an equal decrease in the activity of enzymes - in the cortex at $L_{25}$ it was five times decreased, at $L_{50}$ the decrease was 2.5 times, in the nucleus caudatus at $L_{25}$ it was 3.5 times decreased, and at $L_{50}$ it was 2.5 times decreased, while in the hippocampus the decrease depended on aluminium dose (32\% at $\mathrm{LD}_{25}$, and $62 \%$ at $\left.L D_{50}\right)$. Analogous results were found in chronic aluminium administration (Table 4). The change in glutathione reductase activity is greater than in SOD, which implies that this enzyme is more sensitive to administration of $\mathrm{Al}^{3+}$ on SOD. Since the role of glutathione reductase is very important for maintaining the cellular redox state as this enzyme provides a repeated reduction of - $\mathrm{SH}$ groups on a series of key proteins including enzymes, 
the effects of the drop of the activity can be enormous since insufficient reduction of regulatory proteins causes big changes in cellular metabolism.

Acute $\mathrm{Al}^{3+}$ administration caused dose-dependent increase in the content of MDA, the final product of lipid oxidation, in the cerebral cortex and in hippocampus. In the nucleus caudatus this effect was somewhat less pronounced (Table 4). The increased MDA at $L_{50}$ in spite of the significantly increased SOD activity (Tables $1,2,3)$ may be explained by the fact that not only free radicals formed under the influence of $\mathrm{Al}^{3+}$ can be detoxified by SOD, or that the induced SOD is not biologically efficient.

\section{Conclusions}

In order to obtain a clearer picture of aluminium effects on defense abilities of the brain in relation to the generation of free radicals, the index of maximal damage (IMD) was calculated. It is a cumulative index made up of indices of changes of all three parameters. We calculated the ratio of the smallest enzyme activity and the corresponding control value; for MDA we calculated the ratio of the highest experimental value and control value. The increase in the index indicates a decrease in tissue defense capacities or increase in tissue lipid peroxidation. These indices are added to each other and they make up IMD.

IMD for aluminium in acute administration in the researched brain structures is presented in Figure 1.

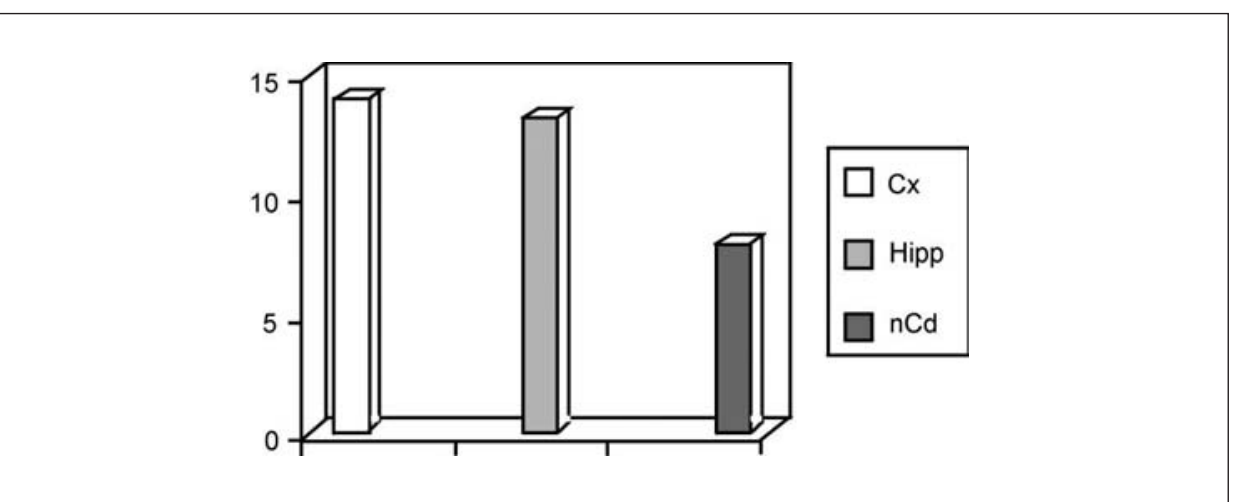

Figure 1. IMD in acute aluminium administration

Acute aluminium administration decreased the activity of both enzymes and increased MDA. Mitochondrial SOD was more sensitive to administration of $\mathrm{Al}^{3+}$ than tissue SOD.

\section{ACKNOWLEDGEMENTS:}

This study was supported by grants from Project ON 175081 of the Ministry of Education, Science and Technological Development of the Republic of Serbia.

Authors would like to express their gratitude to Aleksandra Jović for translation and technical assistance with this paper. 
Milovanović Anđela et al.: Oxido-reductive brain status

after acute aluminium poisoning - the role of free radicals

Address for correspondence:

Dr Aleksandar Milovanović

University of Belgrade, Faculty of Medicine

Serbian Institute of Occupational Health

11000 Belgrade, Serbia

E-mail: milalex@eunet.rs

\section{REFERENCES}

1. Baugh RF, Brown JE, Hougie C, 1975, Plasma components which interfere with ristocetin-induced platelet aggregation, Thromb Diath Haemorrh, 33, 540-6.

2. Begin EM, 1987, Effects of polyunsaturated fatty acids and of their oxidation products on cell survival, Chem Phys Lipids, 45, 269-313.

3. Berry JP, Henoc P, Galle P, 1978, Phagocytosis by cells of the pulmonary alveoli. Transformation of crystalline particles, Am J Pathol, 93, 27-44.

4. Berry JP, Hourdry J, Sternberg M, Galle P, 1982, aluminium phosphate visualisation of acid phosphatase activity: a biochemical and x-ray microanalysis, $J$ Histoch Cytochem, 1, 86-90.

5. Bulat $P, 1995$, Influence of metal on glutathione metabolism in erythrocytes in professional exposition PhD thesis, Medical School, Belgrade.

6. Dean $R T, 1987$, Free radicals, membrane damage and cell-mediated cytolysis, $\mathrm{Br} J$ Cancer 8, 3945.

7. Demopoulos BH Flamm SE, Pietronigro DD, Seligman $L A, 1980$, The free radical pathology and the microcirculation in the major central nervous system disorders, Acta Physiol Scand, Suppl 492, 91-119

8. De Vernejoul MC, 1990, Renal osteodystrophy: aluminium and secondary hyperparathyroidism, Rev Pract, 40, 613-8.

9. Halliwel B, Gutteridge JMC, 1985, The importance of free radicals and catalytic metal ions in human diseses, Molec Aspects Med, 8, 89-93.

10. Ikeda Y, Long DM, 1990, The molecular basis of brain injury and brain edema: the roleof oxygen free radicals, Neurosurgery, 27, 1-11.

11. Joshi JG, 1990, Aluminium, a neurotoxin which affects diverse metabolic reactions, Biofactors, 2 , 163-9.

12. Joshi JG, 1991, Neurochemical hypothesis: participation by aluminium in producing critical mass of colocalized errors in brain leads to neurological disease, Comp Biochem Physiol, 100, 103-5.

13. Kogure K, Arai H, Abe K, Nakano M, 1985, Free radical damage of the brain following ischemia, Prog Brain Res, 63, 237-59.

14. Kong S, Liochev S, Fridovich I, 1992, Aluminium (III) facilitates the oxidation of NADH by the superoxide anion, Free Radic Biol Med, 13, 79-81.

15. Lal B, Gupta A, Murthy RC, Ali MM, Chandra SV, 1993, aluminium ingestion alters behaviour and some neurochemicals in rats, Indian J Exp Biol, 31, 30-5.

16. Lowry OH, Passonneau JV, 1974, A flexible system of enzymatic analysis, Academic Press, New York.

17. Matsumoto M, Kitagawa K, Oda T, Ninobe M, Mikosiba K, Kimura K, 1989, Free radical generation during ischemia may trigger delayed neuronal death, J Cereb Blood Flow Metabol, 9, 556-68.

18. Mazarguil H, Haran R, Laussac J, 1982, The binding of aluminium to (leu) Enkephalin. An investigation using $\mathrm{H}, 13 \mathrm{C}$ and Al NMR, Biochim Biophys Acta, 717, 465-72.

19. Mitrović DR Stanković A, Front $P$, Kuntz $D, 1987$, Is the toxicity of aluminium on tissues due to the production of oxygen free radicals? Presse Med, 16, 1702

20. Mršulja BB, 1981, Brain metabolism and cerebrovascular insufficiency. LEK, Pharmaceutical and Chemical Works, Ljubljana

21. Mršulja BB, 1986, Neurobiologija poremećaja cerebralne cirkulacije. Medicinska knjiga, Beograd 22. Mršulja BB, Mršulja JB, Ito U, Walker TJ, Spatz M, Klatzo I, 1986, Experimental brain ischemia in Mongolian gerbils, Bihevior of biogenic amines, Acta Neuropathol, 361, 1-7 
23. Parker CW, 1987, Lipid mediators produced through the lypoxigenase pathway, Ann Rev Immunol, $5,65-81$

24. Parks $A D$, Granger ND, 1983 , Ischemia-induced vascular changes: role of xanthine oxidase and xydroxyl radicals, Am J Physiol, 245, 285-9.

25. Ramanathan VD, Badenoch P, Turk JL, 1979, Complement activation by aluminium and zirocinum compounds, Immunology, 37, 81-8.

26. Sanderson C, Crapper-McLachlan DR, De Boni U, 1982, Inhibition of corticosterone bindin in vitro, in rabbit hipocampus, by chromatin bound aluninium, Acta Neurophatol, 57, 249-54.

27. Siegel N, Haug A, 1983, Aluminium interaction with calmedulin Evidence for altered structure and function from optical and enzymatix studies, Biochem Biophys Acta, 744, 36-45.

28. Sies $H$, 1985, Oxidative stress. Academic press, London

29. Siesjo KB, 1981, Cell damage in the brain: a speculative sythesis, J Cereb Blood Flow Metabol, 1 , 155-85

30. Slater F, 1989, Disturbances of free radical reactions: a cause or consequence of cell injury? In: Hayaishi O (Ed.): Medical, Biochemical and Chemical Aspects of Free Radicals. Elsevier Science Publishers BV, Amsterdam, 1-9.

31. Stadtman E, 1989, Oxygen radical-mediated inactivation of enzymes: biological implication. In: Hayaishi O (Ed.): Medical, Biochemical and Chemical Aspects of Free Radicals. Elsevier Science Publishers BV, Amsterdam, 11-19.

32. Stahl LW, 1986, The Na, K-ATP-ase of nervous tissue, Neurochem Int, 8, 449-76.

33. Sternweis PC, Gilman AG, 1982, Aluminium: A requirement for activation of the regulatory component of adenylate cyclase by fluorine, PNAS (USA), 79, 4888-91.

34. Sun YA, 1972, The effect of lipoxidation on snaptosomal ( $\mathrm{Na}, \mathrm{K}$ ) ATP-ase isolated from cerebral cortex of squirrel monkey, Biochim Biophys Acta, 266, 350-60.

35. Sun M, Zigman S, 1978, An improved spectrophotometric assay for superoxide dismutase based on epinephrine auto-oxidation, Analyt Biochem, 90, 81-9.

36. Tomimatsu V, Donovan UV, 1976, Spectroscopic evidence for perturbation of tryptophan in AI (III) Ga (III) binding to ovotransferrin and human serum transferrin, FEBS Lett, 71, 299-302.

37. Villacara A Kumami K, Yamamoto T, Mrsulja BB, Spatz M, 1989, Ischemic modification of cerebrocortical membranes: 5-hydroxytryptamine receptors, fluidity, and inducibile in vitro lipid peroxidation, J Neurochem, 53, 2, 595-601.

38. Weiss JS, 1986, Oxygen, ischemia and inflammation, Acta Physiol Scand (Suppl), 548, 9-37

39. Womack FC, Golowick SP, 1979, Proton-dependent inhibition of yeast and brain hexokinases by aluminium in ATP preparations, PNAS, 76, 5080-4.

\section{OKSIDO-REDUKTIVNI STATUS MOZGA NAKON AKUTNE EKSPOZICIJE ALUMINIJUMU - ULOGA SLOBODNIH RADIKALA}

MILOVANOVIĆ ANĐELA, MILOVANOVIĆ J, KONSTATINOVIĆ LJUBICA, VIĆENTIĆ S,
PAVLOVIĆ B, KOJIĆ A, MARMUT Z, ČEMERIKIĆ D, GALJAK M i MILOVANOVIĆ A

\section{SADRŽAJ}

Slobodni radikali pokreću nastajanje oksidativnih procesa koji oštećuju i inaktiviraju mnoge intracelularne komponente i mogu dovesti do smrti ćelije. $U$ ovom radu predstavljeni su rezultati eksperimenata u kojima su korišćeni pustinjski miševi (Džerbili), odrasle jedinke oba pola. Nakon akutne intraperito- 
Acta Veterinaria (Beograd), Vol. 63, No. 2-3, 145-157, 2013.

Milovanović Anđela et al.: Oxido-reductive brain status

after acute aluminium poisoning - the role of free radicals

nealne primene aluminijuma, oksido-reduktivni status mozga ispitivan je u kori velikog mozga, hipokampusu i u nukleus kaudatusu. Zabeleženo je značajno smanjenje odbrambenih kapaciteta mozga - smanjenje aktivnosti enzima, supeoksid dismutase i glutation reduktaze, uz istovremeno povećanje sadržaja malondialdehida, što ukazuje da je pod dejstvom aluminijuma kapacitet mozga da neutrališe superoksidne radikale bitno smanjen i da zbog toga dolazi do povećanog formiranja slobodnih radikala koji oštećuju membranu i dovode do stvaranja malondialdehida iz membranskih lipida, što svakako ima za posledicu narušavanje funkcionalnog integriteta ćelije. Akutno davanje $\mathrm{Al}^{3+}$ dovelo je do dozno-zavisnog povećanja sadržaja malondialdehida u kori velikog mozga i hipokampusu, dok je u nukleus kaudatusu ovaj efekat bio nešto manje izražen. Mitohondrijalna superoksid dismutaza je bila osetljivija na $\mathrm{Al}^{3+}$ od tkivne. 